\title{
Knowledge and Beliefs of Tanta University Employees Regarding Emerging Respiratory Tract Infections and Its Preventive Measures Based on Health Belief Model \\ Hanan Abo El-Gamelen Ebrahim Essa ${ }^{1}$ and Fatma El-Sayed Soliman ${ }^{2}$ \\ ${ }^{1,2}$ Assistant Professors of Community Health Nursing,Faculty of Nursing, Tanta University, Egypt
}

\begin{abstract}
:
Background: The emerging respiratory tract infections (ERTIs) may imply future possible pandemics that present a persistent threat to public health and a huge burden on healthcare services. There is a greater chance for getting ERTIs related to several factors including traditional beliefs and lack of knowledge. Aim: toassess knowledge and beliefs of Tanta university employees regarding ERTIs and its preventive measures based on health belief model (HBM). Design:A descriptive study design was utilized. Settings: five faculties of medical campus that affiliated to Tanta University. Subjects: A Convenience sample of 300 employees working at the previous mentioned settings. Tools: Two tools were used:Tool (I): A Structured interview sheet which included data about bio-socio-demographic characteristics of the studied employees and their knowledge related to the ERTIs and its preventive measures. Tool (II):Beliefs of the studied employees regarding ERTIs based on HBM. Results: More than two fifths of the studied employees had lower level of knowledge regarding the ERTIs and more than half of them had negative beliefs toward ERTIs and its preventive measures. Significant statistical difference was observed between knowledge and beliefs of the studied employees. Conclusion \& Recommendations: The study participants had inadequate knowledge and negative beliefs toward ERTIs and its preventive measures. An extensive educational health campaign should be provided to the public to create awareness and positive attitude and beliefs regarding the ERTIs and its preventive measures.
\end{abstract}

Key words: Emerging respiratory infections, Preventive measures, Knowledge, Beliefs and HBM. 


\section{Introduction:}

Respiratory tract infections (RTIs) constitute a public health problem producing serious consequences for the overall community not only for infected persons ${ }^{(1)}$. Respiratory tract infections are a group of communicable diseases with high secondary attack rates throughout the year (2). It is the most widespread infectious disease in many communities. It has been known to spread progressively by direct contact, circulation of air and using contaminated things ${ }^{(3)}$.

According to World health organization (WHO) 2017, respiratory diseases account for more than $10 \%$ of all disabilityadjusted life-years (DALYs), a metric that estimates the amount of active and productive life lost due to a condition. Respiratory diseases are second only to cardiovascular diseases (including stroke) $(4,5)$.

There are several different causes of RTIs. Mainly, RTIs are caused by viruses or bacteria. Viral respiratory infections can occur in epidemics and spread rapidly within communities across the globe. There are other causes of microorganisms as fungi, and chemicals such as powder or dust that accidentally penetrate into the lungs which could also function as causative agents for RTIs ${ }^{(6,7)}$. Furthermore, many factors are involved in the large variation in the prevalence of transmission of respiratory tract infection including crowdedness, extreme temperature and dense air pollution, young and old age, preexisting health conditions, and improper personal hygiene ${ }^{(8,9)}$.

Emerging respiratory infectious diseases pose a substantial risk to humans due to their extremely high potential to spread from person-to-person. These diseases can produce high morbidity and mortality. There have been several incidents of emerging respiratory infectious diseases in the last century caused by previously unrecognized viruses. These viruses with its capability for mutational changes are of a high potential of transmissibility among humans. It causes a wide range of clinical illnesses ranging from asymptomatic infection to severe hospitalized disease and death. These emerging respiratory infections include the pandemics of Spanish flu, the 'Asian flu, Hong Kong flu, severe acute respiratory syndrome (SARS), the influenza A (H1N1) and recently Covid-19 ${ }^{(10,11)}$.

In 2014, the WHO released the guidelines for infection prevention and control (IPC) of epidemic and pandemic prone acute respiratory diseases in healthcare settings. 
The global strategic precautionary measures for prevention of the emerging RTIs are as follows: mobilize all sectors and communities to ensure that every sector of government and society takes ownership of and participates in the response and in preventing cases through hand hygiene, respiratory etiquette and physical distancing, control sporadic cases and prevent community transmission by rapidly finding and isolating all cases. In addition to providing them with appropriate care, tracing, quarantining, and supporting all contacts. Suppress community transmission through infection prevention and control measures, reduce mortality by providing appropriate clinical care for those affected by respiratory infection and develop safe and effective vaccines and therapeutics that can be delivered at scale and that are accessible based on need ${ }^{(12-14)}$.

Understanding the uptake of preventive measures of RTI is influenced by knowledge and attitudes of certain population. The gap in knowledge, as well as the poor attitudes and bad practices in relation to disease prevention and control, contribute to the increased risk of infection and negative impacts of respiratory diseases (15). Positive attitude and behavioral changes are driven by the level of knowledge and perceptions towards preventive practices ${ }^{(16)}$.

Health belief model (HBM) is one of the oldest and most widely used model which was initially introduced by psychologists Hochbaum, Rosenstock, and Kegels to help people to use free preventive measures for prevention and early detection of disease ${ }^{(17)}$. The HBM encompasses four constructs normally: perceived susceptibility, perceived severity, perceived benefits, and perceived barriers which are the main components of the model (18). Recently, two other constructs have been added to the model including cues for action and self efficacy $^{(17)}$.

Community health nurse has an important role in increasing the awareness of the population about emerging RTIs and their susceptibility to get it ${ }^{(19)}$. As well as educating people about RTIs, its risk factors, signs and symptoms, mode of transmission, its complications and preventive measures $(20,21)$. This could be applied based on assessing the population's knowledge and beliefs about emerging RTIs. The community health nurse has also a challenging role in helping people to adapt health related behaviors to prevent emerging RTIs such as practicing good 
personal hygiene, good nutrition, receiving available vaccines, and use of personal protective devices as musk, face shield and gloves $^{(17)}$.

\section{Significance of the study:}

The best way to prevent and slow down transmission of respiratory infection is be well informed about the disease. Large proportion of the community generally become reluctant to seek care and suffers from morbidity silently. This is because they are restricted with traditional beliefs which may prevent them from following healthy preventive measures and can challenge application of these ${ }^{(17,22)}$. The aim of this study was to assess knowledge and beliefs of Tanta university employees regarding emerging respiratory tract infection and its preventive measures based on health belief model.

\section{Aim of the study:}

The aim of this study was to assess knowledge and beliefs of Tanta university employees regarding emerging respiratory tract infection and its preventive measures based on health belief model.

\section{Research question:}

What are the knowledge and beliefs of Tanta University employees regarding emerging respiratory tract infections and its preventive measures based on health belief model?
Research design: A descriptive study design was utilized in the current study

\section{Settings:}

This study was conducted at the five faculties of medical campus that affiliated to Tanta University which include the faculty of nursing, faculty of medicine, faculty of dentistry, faculty of pharmacy and faculty of science.

\section{Subjects:}

A Convenience sample of 300 employees working at the previous mentioned settings who were willing to participate in the study were included. The sample size was calculated using Epic-Info software statistical package created by World Health Organization (WHO) and center of diseases control and prevention (CDC), Atlanta, Georgia, USA version 2002(Andrew G 2002). The criteria used for the sample size calculation were as following: the study design is cross sectional, 95\% confidence limit expected correlation between the subjects' knowledge and their beliefs is $60 \%$ with a margin of error $10 \%$. The sample size is based on the previously mentioned criteria was found at $n>150$. The total study sample was increased to be 300 employees to increase validity of the results and to compensate the missed information and improving the quality of the collected data. 


\section{Tools of the study:}

Two tools were developed by the researchers to collect the necessary data for this study after reviewing of related literatures.

\section{Tool (I): A Structured questionnaire} schedule:

This tool was developed by the researchers to collect the required data about bio-socio demographic characteristics of the studied subjects and their knowledge regarding emerging respiratory tract infections. It comprised of 21 questions divided into the following parts:-

\section{Part (1):Bio-Socio demographic} characteristics of the employees.Itcomprised of 12 questions that covers data about:

\section{a) Socio demographic characteristics of} the studied employees: Which consisted of six questionssuch as: age, sex, marital status, residence, educational level and occupation.

b) Medical history of employees: It consisted of six questions covered the data about history of respiratory disease, history of chronic diseases, smoking habit, and previous intake of seasonal influenza vaccine.

\section{Part (2): Employees' knowledge about} emerging respiratory tract infections: This part comprised of eight questions 
Tool II:Beliefs of the studied employees regarding emerging respiratory tract infections based on health belief model (HBM) ${ }^{(23)}$.

This tool was developed by the researcher based on the constructs of the original health belief model namely perceived susceptibility, perceived severity,perceived benefits, perceived barriers, perceived cues to action and perceived self-efficacy. It consisted of (37) items, all of them disturbed positively worded except one question negatively worded.

a. Assessment of employees' beliefs regarding perceived susceptibility to emerging RTIs: It comprised of six items which included: their susceptibility to get RTIs especially in crowded places, in inappropriate temperature, bad nutrition, with chronic diseases, with smoking and when contact with infected person with RTI infections.

b. Assessment of employees' beliefs regarding perceived severity to emerging RTIs: It consisted of three items related tocomplications that may occur if RTIs not cured such as pneumonia. As well as, negative effects which can occur with RTI. c. Assessment of employees' beliefs regarding perceived benefits of applying preventive measures: It consisted of seven items describing benefits of using disinfectants in hand washing, benefits of covering nose and mouth, benefits of having seasonal influenza vaccine and generally benefits of applying preventive measures to prevent RTI diseases.

d. Assessment of employees' beliefs regarding perceived barriers to emerging RTIs: It consisted of eight items related to barriers such as being lake of information about RTI preventive methods, unavailability of personal protective devices, difficulty in using mask, get laziness of frequent hand washing, high price of disinfectants materials and embarrassment of using personal protective devices.

e. Assessment of employees' beliefs regarding cues to action for applying emerging RTIs' preventive measures: It consisted of eight items related to cues to action such as previous infection with RTI, easy to get immunization, willing to maintain good health, cheap price of masks and disinfectants, others use for personal protective devices and 
the advices that encourage them to apply RTI preventive measures.

f. Assessment of employees' beliefs regarding self-efficacy in using preventive measures to emerging

RTIs: It consisted of five items such as ability to apply RTI preventive measures in crowding places correctly, ability to follow healthy nutritional regimen, ability to do hand washing with disinfectants correctly and ability to avoid contact with infected persons.

\section{Scoring system:}

A three-point Likert scale was used to measure the employees beliefs as follows: For positive items: Agree item scored (3) points, neutral items scored as (2) points and disagree items scored as (1) points. The score of the negative item was reversed to achieve the right result as follow: Agree (1), natural (2) and disagree (3) points.

The total scores was ranged from (37-111) points thatwas summed up for the six constructs. The total score was calculated then converted into a percent score and classified into two categories as following:

- Negative beliefs $<60 \%$ of the total beliefs score.

○ Positive beliefs $\geq 60 \%$ of the total beliefs score.

\section{Method:}

\section{1) Administrative process (obtaining} approval).

An official permission to conduct this study was obtained from the responsible authority of Faculty of Nursing' and its ethical committee then, it was directed to the Dean of the selected faculties after informing them about the study objectives to gain their permission and cooperation to collect the needed data for this study.

2) Ethical and legal considerations:

-Oral informed consent was obtained from all employees who were included in the study after providing appropriate explanation of the purpose of the study. -Confidentiality and the privacy of the collected data were ensured.

-Nature of the study didn't cause any harm and/or pain for the entire sample.

-Anonymity of participants' responses was guaranteed through using code instead of names.

\section{3) Developing of the study tools:}

-The study tools (tool I and tool П) were developed by the researchers after reviewing relevant literatures.

-The tool was translated into Arabic language to suit the level of understanding of all employees.

-The tools were tested for its face and content validity by a group of five 
experts (three professors from community health nursing, faculty of nursing and two professors of public health and preventive medicine, faculty of medicine Tanta University) before conducting the study. Accordingly, the suggested modifications were done where some questions were omitted and others were paraphrased to suit the studied subjects' understanding level.

-Content validity index for the employees' knowledge about RTI was $93 \%$ while its face validity was $92 \%$. Furthermore, thevalidity of the beliefs' items according to health belief model was $93 \%$ that indicated a good content and face validity of the study tools.

-The reliability of the tool of the study was tested using Cronbach's alpha reliability correlation coefficient test. It was (0.79) which indicated a high reliability.

\section{4) Conducting pilot study:}

A pilot study was carried out on 30 employees ( $10 \%$ of the total subjects) to test the clarity, applicability and comprehension of the tools, estimate the average time needed to collect the necessary data, and identify the obstacles and the problems that may be encountered during data collection. No modifications were done based on the results of pilot study. So, this pilot study group was included in the entire sample of the study.

\section{5) Actual study:}

-The researchers met the employees in their offices three days per week according to the convenient time for both the researchers and the employees.

- The researchers distribute the structured questionnaire schedule to be filled by the participants themselves in the presence of the researchers for providing the needed clarification and guidance.

-The average time spent for collecting data from each person was approximately 20-30 minutes to complete the questionnaire.

- The subjects' sheets were checked by the researchers to be certain that they were filled correctly and completely. The average number of collected sheets was 8-10 sheets /day.

-The field work of this study was accomplished within three months starting from May 2020 to July 2020.

\section{6) Statistical analysis:}

The collected data were organized, tabulated and statistically analyzed using Statistical Package of Social Studies (SPSS) version 20. For numerical data, the range, mean and standard deviation were 
calculated. The association between two variables was calculated by Pearson's correlation coefficient (r). For categorical variables, the number and percentage were calculated. Differences between categories of each variable were statistically analyzed using chi square test $\left(\mathrm{X}^{2}\right)$. When Chisquare was not appropriate, Monte Carlo exact test were used. The level of significance was adopted at $\mathrm{p}<0.05$ and high significant was adopted at $\mathrm{p}<0.001$.

\section{Results:}

Table (I): Shows the distribution of the studied subjects according to their sociodemographic characteristics. Less than half of the studied subjects their ages ranged between 40 - <50 years (46.7\%). Slightly less than one third of them were 50 years or more $(32.7 \%)$. The age of the studied subjects ranged between 22-60 years with a mean of age $51.87 \pm 14.21$ years. More than half of the studied employees were females (56\%). Nearly about two thirds of them were married and from rural residence (68\% and $64.7 \%$ ) respectively. Also, the table revealed that more than one third of them had graduated from universities $(38 \%)$ and more than half of them were working a clerical work $(57.3 \%)$.

Table (2): Presents the distribution of the studied subjects according to their medical condition related to respiratory infections. It was clear that, less than half of the studied subjects suffered from influenza or common cold during the past six months before to the study (47.3\% and $40 \%)$ and more than one quarter of them had sore throat $(26 \%)$. As regard to the frequency of respiratory infections during the past year, the table showed that less than half of the studied subjects had respiratory infection only once / last year (40.7\%) while less than one quarter of them had respiratory infections for three times or more during the past year (24.3\%).

As for suffering from chronic diseases, more than one quarter of the studied subjects mentioned that they had bronchial asthma (27.9\%) and less than one quarter of them had hypertension or diabetes mellitus (24.1\% and $23 \%)$ respectively. Slightly less than three quarters of the studies subjects mentioned that they were previously vaccinated against seasonal influenza (74\%). More than one quarter of the studied employees were smokers (26\%) for less than five years $(41 \%)$ while more than half of them mentioned that they are smoking for more than ten years $(46.2 \%)$.

Table (3): Illustrates the distribution of the studied employees according to their knowledge regarding emerging RTIs. It was obvious that more than half of the 
studied subjects gave complete and correct answer regarding to the risk factors, mode of transmission and sign and symptoms of emerging RTIs $(65.3 \%, 55.3 \%$ and $58 \%)$ respectively. On the other hand, more than three quarters of the studied subjects gave incorrect answer related to the types of emerging RTIs (76.7\%), more than two thirds of them gave incorrect answer of the complications of RTIs (68\%). Also, less than half of them didn't know the definition or causes of emerging RTIs (41.4 and 49.3\%). However, more than one third of the studied employees didn't know the mode of transmission or the preventive measures for emerging RTIs $(33.4 \%$ and $37.3 \%$ ) respectively.

Figure (1): shows the distribution of the studied subjects according to their total level of knowledge about emerging RTIs. This figure showed that less than half of he studied employees either had high level of knowledge or low level of knowledge (42\% and $45 \%)$ respectively. The mean score of knowledge was $6.12 \pm 2.51$.

Figure (2): Shows the distribution of the studied subjects according to their sources of information about emerging respiratory tract infections. It was clear that relatives and friends/neighbors were the main source of information about emerging RTIs among less than three quarters of the studied subjects followed by media (54\%) and internet $(42 \%)$ of the studied subjects. Doctors or nurses and the text book were the source of information for about one third of the studied subjects $(33.3 \%$ and 37.3) respectively.

Table (4): Shows the distribution of the studied subjects according to their beliefs regarding emerging RTIs and its preventive measures based on the different constructs of HBM. Concerning to the studied subjects' beliefs toward their susceptibility to have RTIs It was clear that more than half of the studied subjects (48\%) disagreed that high temperatures and lack of proper nutrition increase the chances of transmission RTIs while more than two fifths of them disagreed that crowded areas, chronic diseases and cigarette smoking increase the chance of RTIs (40. 7\%, 43.4\% and $45.4 \%$ ) respectively. Furthermore, nearly about one third of the studied subjects $(32.6 \%)$ disagreed that their susceptibility of RTIs increases if they are in direct contact with infected person.

As for the belief of the studied subject regarding to the seriousness of emerging RTIs, the table showed that, more than one quarter of the studied subjects disagreed that, they will be a source of infection for others if they get infected with emerging 
RTIs and that emerging RTIs has complications and leads to the occurrence of many chronic diseases such as pneumonia (28\% and 28\%) respectively. Also, one third of them disagreed that, having emerging RTIs may cause a general weakness in their health and affect the completion my tasks $(33.3 \%)$.

Regarding to subjects' beliefs toward benefits of application of preventive measures of emerging RTIs, the table revealed that, more than two fifths of them were uncertain for all the benefits of preventive measures as mentioned in this construct $(42 \%, 43.3 \%, 41.3 \%, 46 \%, 46 \%$, $42 \%$ and $43.3 \%$ ) respectively. Slightly less than one quarter of them disagreed that, taking the flu vaccine can reduce the risk of diseases of respiratory system $(24.7 \%)$. However, more than two fifths of the studied subjects agree on all the benefits of preventive measures $(46.7 \%, 42 \%, 44.7 \%$, $44 \%, 44 \%, 44 \%$ and $46 \%$ ) respectively.

The studied subjects' beliefs toward barriers of preventive measures against emerging RTIs revealed that, slightly less than two thirds of them $(60 \%)$ agreed that shame of wearing personal protective devices (PPD) is a reason not to use it and one third of them agreed that high price of disinfectants is a cause of not using it (33.3\%). Additionally, nearly about one quarter of them agreed that laziness about washing hands several times, (24\%), they can't change their behaviors (23.3\%), Unavailability of water and soap (23.3\%) and difficulty of breathing when wearing mask $(22.7 \%)$ are among the barriers of following preventive measures of emerging RTIs.

As for the subjects' beliefs toward cues of action for the application of preventive measures of RTIs, the highest frequencies of them disagreed that previous attack of RTIs, Easy access to vaccine, the wish to live healthy, physical and psychological comfort, easiness of preventive measures, cheap price and the given advices are the cues of action that encourage them to follow the preventive measures of emerging RTIs $(45.3 \%, 52.7 \%, 74.7 \%$, $83.3 \%, \quad 69.3 \%, \quad 38.7 \%$ and $44 \%$ ) respectively.

Finally, subjects' beliefs toward selfefficiency in using of preventive measures of emerging RTIs revealed that, more than two fifths of the study subjects agreed that they can carry out the protective measures, follow a healthy diet, using clean paper napkins and avoid direct contact with the infected persons $(41.3 \%, 40 \%, 44 \%$ and $44 \%$ ) respectively.

Table (5): shows the distribution of the studied employees according to their total 
score of HBM constructs about emerging RTIs. The table revealed that more than half of the studied employees had negative beliefs regarding all the constructs of $\mathrm{HBM}$ $(58 \%, 52 \%, 53.3 \%, 62.7 \%, 72 \%$ and $57.3 \%)$. Meanwhile, more than two fifths of the studied employees had positive beliefs regarding perceived susceptibility of emerging RTIs, severity of emerging RTIs, benefits of preventive measures of emerging RTIs and perceived selfefficiency in using of preventive measures of emerging RTIs (42\%, 48\%, 46.7\% and $42.7 \%$ ) respectively.

Figure (3): This figure shows the distribution of the studied employees according to their total level of beliefs according to HBM. It was clear that more than half of the studied subjects $(51.3 \%)$ had negative beliefs toward the emerging RTIs and its preventive measures.

Table (6): Presents the correlation between socio-demographic characteristics of studied subjects and their total knowledge scoreabout emerging RTIs. Significant positive correlations were observed between the study employees' total score of knowledge and their age, marital status, level of education and occupation $(<0.001$, $<0.00,0.011$ and 0.002).

Table (7): shows the correlation between socio-demographic characteristics of studied subjects and their total beliefs scoreabout emerging RTIs. Strong significant positive correlations were observed between the study employees' total beliefs score and their age, sex, marital status and level of education $(p=$ $<0.00, \quad 0.003, \quad<0.001$ and $<0.001<0.001$ ) respectively.

Tables (8): This table shows the correlation between total knowledge score of the studied subjects and their beliefs based on health belief model. There were significant positive correlations between the total knowledge score of the studied employees and their beliefs regarding emerging RTIs based on the different constructs of HBM regarding Perceived susceptibility, perceived barriers, perceived cues of action and perceived self efficacy related to emerging RTIs and its prevention $(\mathrm{P}=0.014,0.035,0.005$ and $<0.001)$. Furthermore, there was significant positive correlation between the total knowledge score of the studied employees and their total belief score based on HBM (0.033). This means that the increase of the studied subjects' knowledge is strongly associated to their beliefs regarding emerging RTIs and its preventive measures. 
Table (I): Distribution of the studied subjects according to their socio- demographic characteristics

\begin{tabular}{|c|c|c|}
\hline $\begin{array}{l}\text { Variables of socio- demographic } \\
\text { characteristics }\end{array}$ & $(\mathbf{n}=300)$ & $\%$ \\
\hline \multicolumn{3}{|l|}{ Age } \\
\hline - $\quad<40$ years & 62 & 20.6 \\
\hline - $40-<50$ years & 140 & 46.7 \\
\hline - 50 or more years & 98 & 32.7 \\
\hline $\begin{array}{l}\text { Rang } \\
\text { Mean } \pm \text { SD }\end{array}$ & \multicolumn{2}{|c|}{$\begin{array}{c}22-60 \\
51.87 \pm 14.21 \\
\end{array}$} \\
\hline \multicolumn{3}{|l|}{ Sex } \\
\hline - Females & 168 & 56.0 \\
\hline - Males & 132 & 44.0 \\
\hline \multicolumn{3}{|l|}{ Marital status } \\
\hline - $\quad$ Married & 204 & 68.0 \\
\hline - Single & 18 & 6.0 \\
\hline - Widow & 66 & 22.0 \\
\hline - $\quad$ Divorced & 12 & 4.0 \\
\hline \multicolumn{3}{|l|}{ Place of residence } \\
\hline - Rural & 97 & 64.7 \\
\hline - Urban & 53 & 35.3 \\
\hline \multicolumn{3}{|l|}{ Level of education } \\
\hline - Basic Education & 94 & 31.3 \\
\hline - Secondary education & 92 & 30.7 \\
\hline - University education & 114 & 38.0 \\
\hline \multicolumn{3}{|l|}{ Occupation } \\
\hline - Administrative job & 48 & 16.0 \\
\hline - $\quad$ Clerical work & 172 & 57.3 \\
\hline - Workers & 80 & 26.7 \\
\hline
\end{tabular}


Table (2): Distribution of the studied subjects according to their medical conditionrelated to respiratory infections

\begin{tabular}{|c|c|c|}
\hline Medical and Health History of study subjects & $\mathbf{n}=\mathbf{3 0 0}$ & $\%$ \\
\hline \multicolumn{3}{|l|}{ *Respiratory problems during the past six months } \\
\hline - Influenza & 142 & 47.3 \\
\hline - Bronchitis & 28 & 9.3 \\
\hline - Common Colds & 120 & 40.0 \\
\hline - Sore throat & 78 & 26.0 \\
\hline - $\quad$ Severe pneumonia & 12 & 4.0 \\
\hline - Asthma & 28 & 9.3 \\
\hline - Sinusitis & 12 & 3.7 \\
\hline - $\mathrm{TB}$ & 16 & 5.7 \\
\hline Frequency of respiratory infections during the past year & \multicolumn{2}{|c|}{$(n=206)$} \\
\hline - Once & 84 & 40.7 \\
\hline - Twice & 72 & 35.0 \\
\hline - Three times or more & 50 & 24.3 \\
\hline *Suffering from chronic diseases & \multicolumn{2}{|c|}{$(n=208)$} \\
\hline - Cardiac diseases & 18 & 8.7 \\
\hline - Hypertension & 50 & 24.1 \\
\hline - $\quad$ Bronchial asthma & 58 & 27.9 \\
\hline - diabetic mellitus & 48 & 23 \\
\hline - Rheumatic diseases & 34 & 16.3 \\
\hline \multicolumn{3}{|l|}{ Previous take of seasonal influenza vaccine } \\
\hline - Yes & 222 & 74.0 \\
\hline - $\mathrm{No}$ & 78 & 26 \\
\hline \multicolumn{3}{|l|}{ Smoking } \\
\hline - Yes & 78 & 26.0 \\
\hline - $\mathrm{No}$ & 222 & 74.0 \\
\hline Duration of smoking & \multicolumn{2}{|c|}{$(n=78)$} \\
\hline - Less than 5 years & 32 & 41.0 \\
\hline - From 5-10 years & 10 & 12.8 \\
\hline - More than 10 years & 36 & 46.2 \\
\hline
\end{tabular}

* More than one answer was allowed. 
Table (3): Distribution of the studied employees according to their knowledge regarding of emerging RTIs.

\begin{tabular}{|c|c|c|c|c|c|c|}
\hline \multirow{3}{*}{ Items of employees' knowledge } & \multicolumn{6}{|c|}{$\begin{array}{l}\text { Knowledge level of the studied employees } \\
\qquad(n=300)\end{array}$} \\
\hline & \multicolumn{2}{|c|}{$\begin{array}{l}\text { Complete } \\
\text { Correct }\end{array}$} & \multicolumn{2}{|c|}{$\begin{array}{l}\text { Incomplete } \\
\text { correct }\end{array}$} & \multicolumn{2}{|c|}{$\begin{array}{l}\text { Incorrect/ don't } \\
\text { know answer }\end{array}$} \\
\hline & $\mathrm{N}$ & $\%$ & $\mathrm{~N}$ & $\%$ & $\mathrm{~N}$ & $\%$ \\
\hline Definition ofemerging RTIs. & 148 & 49.3 & 28 & 9.3 & 124 & 41.4 \\
\hline Causes of emerging RTIs. & 108 & 36.0 & 44 & 14.7 & 148 & 49.3 \\
\hline Risk factors of emerging RTIs & 196 & 65.3 & 134 & 11.3 & 70 & 23.4 \\
\hline Types of emerging RTIs. & 30 & 10.0 & 20 & 13.3 & 115 & 76.7 \\
\hline $\begin{array}{l}\text { Mode of transmission of emerging } \\
\text { RTIs. }\end{array}$ & 166 & 55.3 & 34 & 11.3 & 100 & 33.4 \\
\hline $\begin{array}{l}\text { Signs and symptoms of emerging } \\
\text { RTIs. }\end{array}$ & 174 & 58.0 & 44 & 14.7 & 82 & 27.3 \\
\hline Complications of emerging RTIs. & 64 & 21.3 & 32 & 10.7 & 204 & 68 \\
\hline $\begin{array}{l}\text { Methods of prevention of emerging } \\
\text { RTIs }\end{array}$ & 128 & 42.7 & 60 & 20.0 & 112 & 37.3 \\
\hline
\end{tabular}

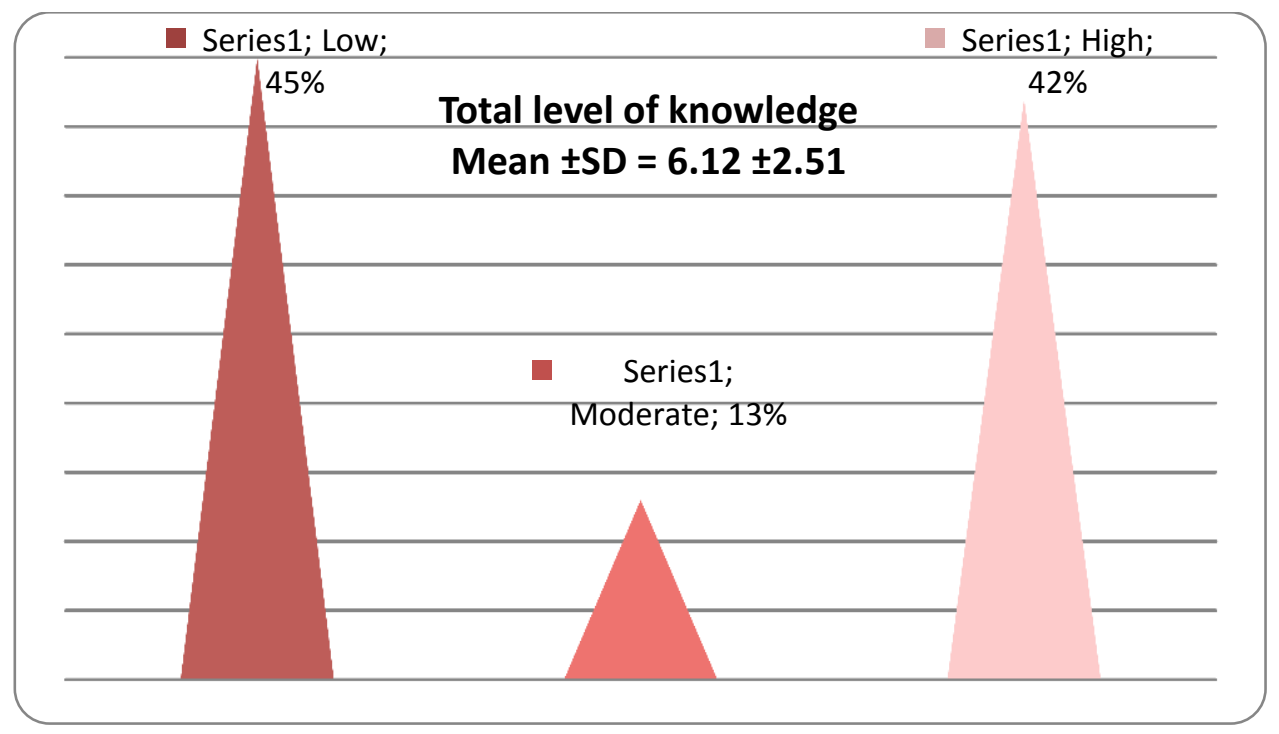

Figure (1): Distribution of the studied subjects according to their total level of knowledge about emerging RTIs 


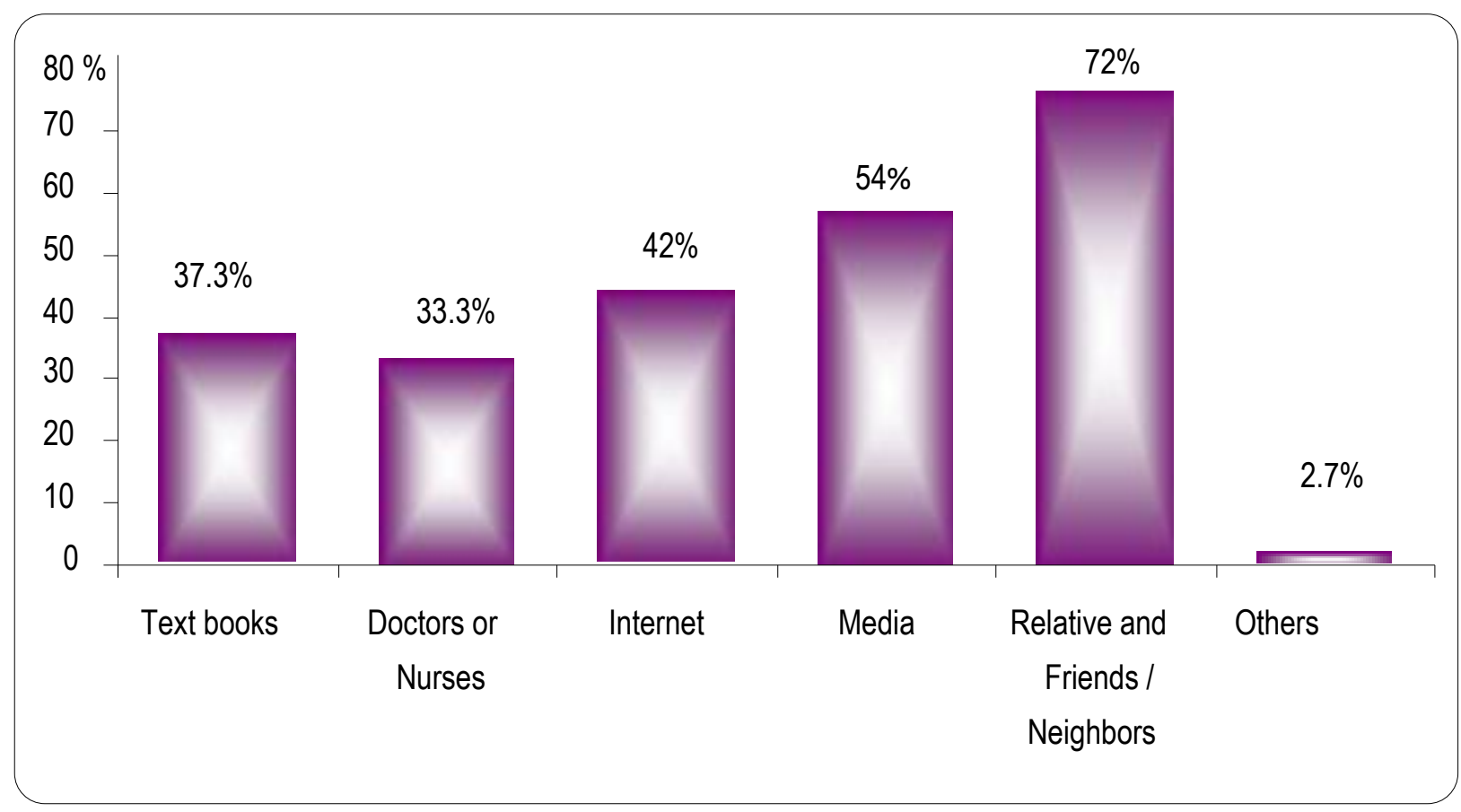

Figure (2): Distribution of the studied subjects according to their sources of information aboutemergingrespiratory tract infections (more than one answer allowed)

Table (4): Distribution of the studied subjects according to their beliefs regarding emerging RTIs and its preventive measures based on the different constructs of HBM

\begin{tabular}{|c|c|c|c|c|c|c|}
\hline \multirow{3}{*}{ Beliefs items } & \multicolumn{6}{|c|}{$\begin{array}{l}\text { Subjects' beliefs regarding emergingRTIs } \\
\text { and its preventive measures based on the } \\
\text { different constructs of HBM }\end{array}$} \\
\hline & \multicolumn{2}{|c|}{ Agree } & \multicolumn{2}{|c|}{ Uncertain } & \multicolumn{2}{|c|}{ Disagree } \\
\hline & No & $\%$ & No & $\%$ & No & $\%$ \\
\hline \multicolumn{7}{|c|}{ 1. The studied subjects' beliefs toward their susceptibility to have emergingRTIs } \\
\hline $\begin{array}{l}\text { I think that my chances of getting RTIs increase } \\
\text { at the crowded areas }\end{array}$ & 59 & 39.3 & 30 & 20.0 & 61 & 40.7 \\
\hline $\begin{array}{l}\text { I think that high temperatures and lack of proper } \\
\text { nutrition increase the chances of transmission } \\
\text { RTIs }\end{array}$ & 50 & 33.3 & 28 & 18.7 & 72 & 48 \\
\hline $\begin{array}{l}\text { I think that chronic diseases such as diabetes or } \\
\text { hypertension increase the risk of RTIs }\end{array}$ & 44 & 29.3 & 41 & 27.3 & 65 & 43.4 \\
\hline $\begin{array}{l}\text { I think that cigarette smoking increases my } \\
\text { chance of getting RTIs }\end{array}$ & 59 & 39.3 & 23 & 15.3 & 68 & 45.4 \\
\hline $\begin{array}{l}\text { I think that I'm more susceptible to RTIs if I in } \\
\text { direct contact with someone who is infected with } \\
\text { respiratory tract infection. }\end{array}$ & 85 & 56.7 & 16 & 10.7 & 49 & 32.6 \\
\hline $\begin{array}{l}\text { I think that I will never have RTIs due to } \\
\text { crowdedness. }\end{array}$ & 82 & 54.7 & 40 & 26.7 & 28 & 18.6 \\
\hline \multicolumn{7}{|c|}{ 2. The studied subjects' beliefs toward severity/seriousness of emerging RTIs } \\
\hline $\begin{array}{l}\text { I think that having RTIs may cause a general } \\
\text { weakness in my health and affect the completion } \\
\text { my tasks. }\end{array}$ & 46 & 30.7 & 54 & 36 & 50 & 33.3 \\
\hline
\end{tabular}

Vol. 20 No. 1 (Suppl)February, 2021 


\begin{tabular}{|c|c|c|c|c|c|c|}
\hline $\begin{array}{l}\text { I think that RTI has complications and leads to } \\
\text { the occurrence of many chronic diseases such as } \\
\text { pneumonia. }\end{array}$ & 49 & 32.7 & 59 & 39.3 & 42 & 28.0 \\
\hline $\begin{array}{l}\text { I think that I may be a source of infection for } \\
\text { others when I get infected with RTI. }\end{array}$ & 47 & 31.3 & 61 & 40.7 & 42 & 28.0 \\
\hline \multicolumn{7}{|c|}{$\begin{array}{l}\text { 3. Studied subjects' beliefs toward benefits of application of preventive measures of } \\
\text { emerging RTI }\end{array}$} \\
\hline $\begin{array}{l}\text { I think that using soap or alcohol reduces the } \\
\text { infection of respiratory system. }\end{array}$ & 70 & 46.7 & 63 & 42.0 & 17 & 11.3 \\
\hline $\begin{array}{l}\text { I do not worry of RTIs if I cover my mouth and } \\
\text { nose with a sanitary mask. }\end{array}$ & 63 & 42.0 & 65 & 43.3 & 22 & 14.7 \\
\hline $\begin{array}{l}\text { I do not worry of RTIs transmission if I use } \\
\text { paper napkins on coughing in crowding places. }\end{array}$ & 67 & 44.7 & 62 & 41.3 & 21 & 14.0 \\
\hline $\begin{array}{l}\text { When I get away from the crowd, I will have no } \\
\text { chance of getting infected with RTIs. }\end{array}$ & 66 & 44.0 & 69 & 46.0 & 15 & 10.0 \\
\hline $\begin{array}{l}\text { Following preventive measures can protect me } \\
\text { from RTIs. }\end{array}$ & 66 & 44.0 & 69 & 46.0 & 15 & 10.0 \\
\hline $\begin{array}{l}\text { Taking the flu vaccine can reduce the risk of } \\
\text { diseases of respiratory system }\end{array}$ & 50 & 33.3 & 63 & 42.0 & 37 & 24.7 \\
\hline $\begin{array}{l}\text { Knowing the guidance from the medical team } \\
\text { reduces the chances of my infection with RTIs. }\end{array}$ & 69 & 46.0 & 65 & 43.3 & 16 & 10.7 \\
\hline \multicolumn{7}{|c|}{$\begin{array}{l}\text { 4. The studied subjects' beliefs toward barriers of preventive measures against emerging } \\
\text { RTIs }\end{array}$} \\
\hline $\begin{array}{l}\text { Unawareness of methods of prevention from } \\
\text { RTIs and methods of transmission is the cause of } \\
\text { the spread of RTIs. }\end{array}$ & 12 & 8.0 & 66 & 44.0 & 72 & 48.0 \\
\hline $\begin{array}{l}\text { The difficulty of obtaining personal protection } \\
\text { and their unavailability does not enable me to } \\
\text { wear them. }\end{array}$ & 30 & 20.0 & 52 & 34.7 & 68 & 45.3 \\
\hline $\begin{array}{l}\text { The difficulty of breathing when wearing mask } \\
\text { prevents me from using it. }\end{array}$ & 34 & 22.7 & 88 & 58.7 & 28 & 18.7 \\
\hline $\begin{array}{l}\text { I can't change my behavior even though I know } \\
\text { I am wrong. }\end{array}$ & 35 & 23.3 & 53 & 35.3 & 62 & 41.3 \\
\hline $\begin{array}{l}\text { Laziness about washing my hands several times } \\
\text { is one of the barriers. }\end{array}$ & 36 & 24.0 & 65 & 43.3 & 49 & 32.7 \\
\hline $\begin{array}{l}\text { High price of disinfectants is a cause of not } \\
\text { using it. }\end{array}$ & 50 & 33.3 & 57 & 38.0 & 43 & 28.7 \\
\hline $\begin{array}{l}\text { Unavailability of water and soap outside home } \\
\text { prevents me from washing my hands frequently. }\end{array}$ & 35 & 23.3 & 65 & 43.3 & 50 & 33.3 \\
\hline $\begin{array}{l}\text { Shame of wearing personal protective devices } \\
\text { (PPD) is a reason not to use it. }\end{array}$ & 90 & 60.0 & 33 & 22.0 & 27 & 18 \\
\hline \multicolumn{7}{|c|}{ 5. Beliefs toward cues of action for the application of preventive measures ofemergingRTIs } \\
\hline $\begin{array}{l}\text { I have a previous attack of RTIs and I do not } \\
\text { want to repeat the infection again }\end{array}$ & 52 & 34.7 & 30 & 20.0 & 68 & 45.3 \\
\hline Easy access to vaccine encourages me to take it & 15 & 10.0 & 56 & 37.3 & 79 & 52.7 \\
\hline I wish to live healthy & 31 & 20.7 & 7 & 4.7 & 112 & 74.7 \\
\hline $\begin{array}{l}\text { I feel physical and psychological comfort when I } \\
\text { do not suffer from respiratory diseases }\end{array}$ & 20 & 13.3 & 5 & 3.3 & 125 & 83.3 \\
\hline $\begin{array}{l}\text { The easiness of preventive measures encourages } \\
\text { me to follow it }\end{array}$ & 36 & 24.0 & 10 & 6.7 & 104 & 69.3 \\
\hline
\end{tabular}




\begin{tabular}{|l|l|l|l|l|l|l|}
\hline $\begin{array}{l}\text { Cheap masks and disinfectants needed to fight } \\
\text { the infection encourage me to use them }\end{array}$ & 37 & 24.7 & 55 & 36.7 & 58 & 38.7 \\
\hline Others' use of PPD motivates me to imitate them & 40 & 26.7 & 61 & 40.7 & 49 & 32.7 \\
\hline $\begin{array}{l}\text { The advices I heard encourages me to apply } \\
\text { prevention measures }\end{array}$ & 41 & 27.3 & 43 & 28.7 & 66 & 44.0 \\
\hline 6. Beliefs toward self-efficiency in using of preventive measures of emerging RTIs \\
\hline $\begin{array}{l}\text { I can carry out the protective measures and wear } \\
\text { the mask properly in the crowded areas. }\end{array}$ & 62 & 41.3 & 70 & 46.7 & 18 & 12.0 \\
\hline $\begin{array}{l}\text { I can follow a healthy diet rich in vitamin "C" to } \\
\text { increase body resistance to emerging RTIs. }\end{array}$ & 60 & 40.0 & 72 & 48.0 & 18 & 12.0 \\
\hline $\begin{array}{l}\text { I can avoid coughing in the face of others by } \\
\text { using always clean paper napkins. }\end{array}$ & 66 & 44.0 & 49 & 32.7 & 35 & 23.3 \\
\hline $\begin{array}{l}\text { I can clean my hands by the right way and use } \\
\text { the appropriate disinfectants constantly. }\end{array}$ & 53 & 35.3 & 64 & 42.7 & 33 & 22.0 \\
\hline $\begin{array}{l}\text { I can avoid direct contact with the patients with } \\
\text { RTIs }\end{array}$ & 66 & 44.0 & 34 & 22.7 & 50 & 33.3 \\
\hline
\end{tabular}

Table (5): Distribution of the studied employees according to their total score of HBM constructs about emerging RTIs and its prevention

\begin{tabular}{|c|c|c|c|c|}
\hline \multirow{3}{*}{$\begin{array}{c}\text { Different construct of health belief } \\
\text { model }\end{array}$} & \multicolumn{4}{|c|}{$\begin{array}{c}\text { Employees' beliefs regarding emerging } \\
\text { RTIs }(\mathrm{n}=300)\end{array}$} \\
\hline & \multicolumn{2}{|c|}{ Positive } & \multicolumn{2}{|c|}{ Negative } \\
\hline & $\mathrm{N}$ & $\%$ & $\mathrm{~N}$ & $\%$ \\
\hline Perceived susceptibility of emerging RTIs. & 126 & 42.0 & 174 & 58.0 \\
\hline Perceive severity of emerging RTIs. & 144 & 48.0 & 156 & 52.0 \\
\hline $\begin{array}{l}\text { Perceived benefits of the application of } \\
\text { preventive measures of emerging RTIs. }\end{array}$ & 140 & 46.7 & 160 & 53.3 \\
\hline $\begin{array}{l}\text { Perceived barriers of preventive measures } \\
\text { against emerging RTIs. }\end{array}$ & 112 & 37.3 & 188 & 62.7 \\
\hline $\begin{array}{l}\text { Perceived cues of action for the application } \\
\text { of preventive measures of emerging RTIs. }\end{array}$ & 84 & 28.0 & 216 & 72.0 \\
\hline $\begin{array}{l}\text { Perceived self-efficiency in using of } \\
\text { preventive measures of emerging RTIs. }\end{array}$ & 128 & 42.7 & 172 & 57.3 \\
\hline
\end{tabular}




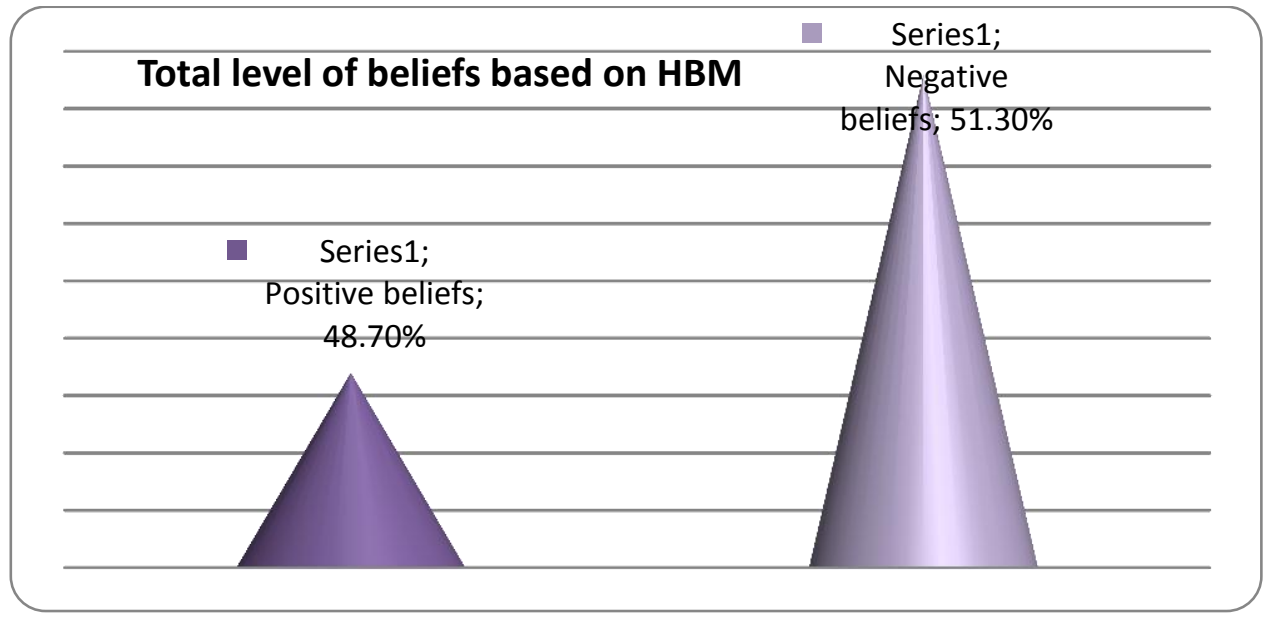

Figure (3): Distribution of the studied employees according to their total level of beliefs based on HBM

Table (6): Correlation between socio-demographic characteristics of the studied employees and their total knowledge score about emerging RTIs

\begin{tabular}{|c|c|c|}
\hline \multirow{2}{*}{$\begin{array}{c}\text { Socio-demographic } \\
\text { characteristics of the } \\
\text { employees }\end{array}$} & \multicolumn{2}{|c|}{ Total knowledge score } \\
\cline { 2 - 3 } & $\mathrm{r}$ & $\mathrm{P}$ \\
\hline Age & 0.460 & $<0.001^{*}$ \\
\hline Sex & 0.167 & 0.168 \\
\hline Marital status & 0.378 & $<0.001^{*}$ \\
\hline Level of education & 0.303 & $0.011^{*}$ \\
\hline Occupation & 0.375 & $0.002^{*}$ \\
\hline
\end{tabular}

*Significant at $\mathrm{p}<0.05$

Table (7): Correlation between socio-demographic characteristics of studied employees and their total beliefs score about emerging RTIs

\begin{tabular}{|l|c|c|}
\hline \multirow{2}{*}{$\begin{array}{c}\text { Socio- demographic } \\
\text { characteristics of employees }\end{array}$} & \multicolumn{2}{|c|}{ Employees' total beliefs score } \\
\cline { 2 - 3 } & $\mathrm{r}$ & P-value \\
\hline Age & 0.395 & $<0.001^{*}$ \\
\hline Sex & 0.234 & $0.003^{*}$ \\
\hline Marital status & 0.401 & $<0.001^{*}$ \\
\hline Level of education & 0.332 & $<0.001^{*}$ \\
\hline Occupation & 0.145 & 0.186 \\
\hline
\end{tabular}

*Significant at $\mathrm{p}<0.05$

Vol. 20 No. 1 (Suppl)February, 2021 
Tables (8): Correlation between total knowledge score of the studied employees and their beliefs based on health belief model

\begin{tabular}{|l|c|c|}
\hline \multicolumn{1}{|c|}{$\begin{array}{c}\text { constructs of } \\
\text { health belief model }\end{array}$} & \multicolumn{2}{c|}{$\begin{array}{c}\text { Total knowledge of the studied } \\
\text { subjects }\end{array}$} \\
\cline { 2 - 3 } & $\mathrm{r}$ & $\mathrm{P}$ \\
\hline Perceived susceptibility of emerging RTIs & 0.219 & $0.014^{*}$ \\
\hline Perceived severity of emerging RTIs & 0.098 & 0.207 \\
\hline $\begin{array}{l}\text { Perceived benefits of the application of preventive } \\
\text { measures of the emerging RTIs }\end{array}$ & 0.152 & 0.209 \\
\hline $\begin{array}{l}\text { Perceived barriers of preventive measures of emerging } \\
\text { RTIs }\end{array}$ & 0.226 & $0.035^{*}$ \\
\hline $\begin{array}{l}\text { Perceived cues of action for the application of } \\
\text { preventive measures of emerging RTIs }\end{array}$ & 0.231 & $0.005^{*}$ \\
\hline $\begin{array}{l}\text { Perceived self-efficiency in using of preventive } \\
\text { measures of emerging RTIs }\end{array}$ & 0.430 & $<0.00 *^{* *}$ \\
\hline Total beliefs of the studied pilgrims & 0.0172 & $0.033^{*}$ \\
\hline
\end{tabular}

*Significant at $\mathrm{p}<0.05$

$* *$ Significant at $\mathrm{p}<0.01$ 


\section{Discussion:}

Acute respiratory infections are prevalent and pose a constant threat to society ${ }^{(24)}$. Respiratory tract infections (RTIs) are of greater importance because it can contribute to the rapid globalization of emerging pathogens and can raise the risk for epidemics on a grand scale. In past decades, we have seen several epidemics of respiratory infections from newly emerging viruses which have shown a high speed of transmission (11). Viral acute respiratory infections (ARIs) represent a huge burden on global health. Preventing the infection from spreading amongst people may be the only option to reduce the spread of outbreaks ${ }^{(25)}$.

This highlights the occupational safety and health $(\mathrm{OSH})$ risks arising from the spread of infection. It also explores measures to prevent and control the risk of workrelated safety and health risks associated with the pandemic (26). This could be managed through assessing knowledge and beliefs of the entire population who are at risk to the infection. Health belief model (HBM) is one of the models used to promote preventive behaviors through assessing and improving person's beliefs regarding the health problem. Knowledge as well is a dominant factor which can affect person's beliefs and behaviors. So, the aim of this study was to assess knowledge and beliefs of Tanta university employees regarding emerging respiratory tract infections and its preventive measures based on health belief model.

The results of the current study revealed that the mean age of the studied subjects was $51.87 \pm 14.21$ years. The highest frequencies of the studied subjects were married, females and of the middle age (40 - <50 years) (Table 1). This could be attributed to the Egyptian policy that limit the number of new employment and increased number of Egyptian independent females. This finding coincides with the (Ogolodom MP, Mbaba AN, 2020) (27), who found that, the majority of the participants were young adults, females and married. In the same context, Wong et al., $(\mathbf{2 0 2 0})^{(28)}$, revealed that the mean age of the participants was 38.92 years and $59.7 \%$ of them were females. Also, Souli and Dilucca, (2020) ${ }^{(29)}$, reported that $59.3 \%$ were females.

On the other hand, these findings disagree with Gudiet al., (2020) ${ }^{(30)}$, who found that the mean age of their study participants was $28.8 \pm 10.9$ years, where the majority of them belong to the age category $<25$ years and more than half of their participants, were males. 
The results of the current study revealed that the highest frequencies of the studied employees had low level of knowledge about emerging RTIs (Fig.1). This could be attributed to their level of education where the highest percentages of the studied employees had either basic or secondary education. In the same line, Wong et al., (2020) ${ }^{(28)}$, reported that the participants' overall correct response rate on the knowledge test was relatively low.

This result is disagree with the study of Joshi et al., (2020) ${ }^{(31)}$ and Modi et al., (2017) ${ }^{(32)}$, who found that the overall correct responses of knowledge and awareness of participants were satisfactory. In the same line, Abdur Rahman and Sathi (2020) ${ }^{(33)}$, found that the overall correct knowledge is $63.3 \%$. The educational levels of the studied populations might explain this discrepancy between studies and could be attributed to the difference in settings as they assess the knowledge of health care students while our participants were employees.

Also, it was found that there was positive significant correlation between the total knowledge of the studied employees and their level of education (Table VI). This is supported by Diaz-Quijano et al., (2017) (34) who stated that there was significant association between their studied subjects' education and their level of knowledge. In the same context, Wong et al., (2020) ${ }^{(28),}$ found that one fifth of the participants (20.5\%) had an education level of primary school or lower, while $46.6 \%$ had received a secondary school education and $33.0 \%$ had received tertiary education or higher.

During outbreaks of emerging respiratory tract infections, information regarding this disease, risk factors, mode of transmission and safety measures should be selflessly promoted by the news channels, print media, radio stations, and social media, as almost every individual relates to either of these platforms at some point in a day. Contradictory, the result of the current study revealed that, relatives and friends/neighbors were the main source of employees' information about emerging RTIs which explain the lower level of their knowledge about emerging RTIs (Fig. 2).

This could be attributed to the nature of Egyptian community that prefers to share information and experience with each other which magnify the emphasis on social media, especially WhatsApp and Messenger applications. According to the result of current study, the media and internet were the second source of information (54\% and $42 \%$ of the studied employees respectively) which may be due to the nature of our participants who were 
old employees. Those aged between 40 and 60 years, the primary demographic of this study, who have no time and less technological experience usually depend less on internet for information than any other age group which make the chance to have the correct knowledge and information from the these source is low.

Similarly, Ogolodom MP et al., (2020) ${ }^{(35)}$, stated that the most common source of their information was through colleagues (47.67\%), followed by social media (26\%). Also, Nour et al., (2015) ${ }^{(36)}$, reported that, slightly more than half of studied sample depended on internet and social media as a main source of knowledge about MERS$\mathrm{CoV}$ and a considerable percent (44.8 and 43.4\%) depended on T.V and health educator respectively while the least source was radio.

On the other hand, our result contradict with Dwivedi et al., (2017) ${ }^{(37)}$, who stated that social media plays a critical role in connecting people to new friends and allowing them to gain knowledge. Also, other study about COVID-19 that was conducted by Souli and Dilucca, (2020) (29), revealed that TV and websites are the most sources of participants' information. Additionally, Hassan et al., (2020) ${ }^{(38)}$, reported that in nearly all previous studies (including Egypt) about COVID- 19, the novel methods of communications, social media (commonly Facebook and WhatsApp) were the main source of information.

The level of knowledge can be influenced by different factors. Many studies found that people's knowledge can be affected by their socio-demographic characteristics. The present study showed that, there were high significant positive correlations between the total knowledge score of the studied employees and their age, marital status, level of education and occupation(Table VI). This could be explained that people with advanced age can gain more knowledge from their life experiences and married people could found support and help in getting information. As well, working can increases the chance and ability to learn and gain knowledge.

This is in agreement with Abdur Rahman and Sathi, (2020) ${ }^{(33)}$,Nour, et al., (2015) (36) andZhong et al., (2020) ${ }^{(39)}$ who reported that, knowledge score significantly varies with different age groups, gender, education, occupation, marital status and residence type. Additionally, Kale et al.,(2015) (40), revealed that there was significant association betweensocio-demographic factors and health awareness among 
elderly individuals with COPD.Abdelhafiz and Alorabi, (2020) ${ }^{(41)}$, also revealed that there was significant association between socio-demographic factors of Egyptian public and their awareness towards the COVID-19 disease.

Assessing the public knowledge about emerging RTIs is becoming more important. In our study, we found that more than half of the studied employees gave complete and correct answer regarding the risk factors, mode of transmission and sign and symptoms of emerging RTIs. Also, Souli and Dilucca, (2020) ${ }^{(29)}$, stated that a quite good level of perception about the disease risk factors was found among their participants.

This may be attributed to their life experience and could be explained as less than half of the studied employees suffered from influenza or common cold during the past six months before to the study and more than one quarter of them had sore throat which gave them the chance to identify the mode of transmission and manifestations of the disease. This is in disagreement with Wong et al., (2020) ${ }^{(28)}$, who reported that their participants expressed a lower level of knowledge about the transmission and risk factors of COVID-19.
However, more than one third of the studied employees gave incorrect answer ordon't know the preventive measures for emerging RTI. This may be an indication for the stress need to disseminate the correct information about preventive measures for emerging RTIs to all populations through direct methods of education. This becomes more important especially in the current outbreak of novel corona virus, which given the need for plausible parameters for modeling efforts for human corona virus Spencer et al., (2020) ${ }^{(42)}$. In the same line, Elgzar et al., (2020) ${ }^{(43)}$, reported that a large proportion of their participants initially had incomplete awareness regarding signs, and preventive practice of COVID- 19. On the other hand, Goni et al., (2019) ${ }^{(22)}$, nearly reported different results regarding the knowledge of preventive practices of RTIs, where they found that most of the participants $(81.3 \%)$ knew RTIs could be prevented by following: a healthy diet $(89.8 \%)$, receiving vaccinations $(83.1 \%)$, washing hands with hand sanitizers $(87.1 \%)$ and wearing a face mask $(90.7 \%)$. The success of prevention of infectivity e.g. engaging in precautionary behaviors such as (wearing masks, hand hygiene, isolation etc.), vaccination, contact tracing and population screening are all often the 
only means of prevention of a further spread of the disease especially in the early phases of a possible epidemic Brug et al., (2009) ${ }^{(44)}$. Egypt is the most populous country in the Middle East. Adherence to preventive precautions is essential to prevent the crisis in Egypt.

To get the required level of adherence, it is important to evaluate the population's knowledge and beliefs regarding the emerging RTIs. Health belief model is based on the idea that changing the health belief is of significant importance for behavior change Barakat and Kasemy, (2020) ${ }^{(45)}$. So, in the current study, we assess the employees' perception of their susceptibility to catch respiratory infections, severity of the disease, benefits or barriers for following preventive measures in addition to their perception of cues to action and self-efficacy in following the preventive measures based on the health belief model.

As a general, the results of the current study revealed that, more than half of the studied employees had negative beliefs toward the emerging RTIs and its preventive measures (Fig. 3). This result is supported by the results of Goni et al., (2019) ${ }^{(22)}$, and Abdul Rahman and Sathi, (2020) ${ }^{(33)}$, who found that, the majority of their studied sample had a negative or unacceptable attitude towards the prevention of respiratory tract infections. A possible explanation of this attitude can be due to the rapid spreading of the disease even in developed countries. However, this finding contradicts the attitude of Chinese Zhong et al., (2020) (39), and Indian respondents Ahmad et al., (2016) (46) toward COVID-19 and Ebola respectively. This difference may be due to the governmental attitude towards explaining the actual situation of the pandemic and the commitment of their population in addition to the difference of subjects' socio demographic characteristics.

Understanding the people's perception of risk is important to ensure efficient health protection practices during virus outbreaks. Regarding perceived susceptibility and severity, the current study illustrated that, more than half of the studied employees disagreed that they are susceptible to emerging RTIs and showed a negative beliefs about perceived susceptibility and severity of emerging RTI (Table IV). The highest frequencies of the studied employees didn't think that crowdedness, extreme temperature, having chronic diseases and cigarettes smoking may increase their susceptibility of RTIs. Furthermore, they didn't think that RTIs may cause general weakness or other 
complications as pneumonia or they may be a source of infection for others. In the same line, Wong et al., (2020) ${ }^{(28)}$, also their participants expressed certain misconceptions regarding their susceptibility to COVID-19 infection. They perceived a mild risk related to the disease. This could be because of the discrepancy of manifestations between seasonal infections, common cold attacks that usually self limited and relived without medical intervention and emerging diseases as COVID-19 which may most of participants did not have it yet.

In contrast to this result, Hassan N. et al., (2020) ${ }^{(38)}$ pointed that the vast majority of their participants believe in their susceptibility to have RTIs. Moreover, about three quarters of them believe in seriousness of the disease. Also, Ogolodom MP et al., (2020) ${ }^{(35)}$ and Zegarra-Valdivia et al., (2020) ${ }^{(47)}$, who assessed the risk perception and attitude of healthcare workers towards COVID-19 reported that the majority of the participants perceived themselves at risk of being infected by the virus due to going to work and most of the participants strongly agreed that they are prone to having the infection. This may be attributed to the differences of the nature of the work of the study sample where our subjects were employees while others' were health care workers who are actually more susceptible to infection due to their frequent contact with patients.

Perceived benefits which people will gain from applying preventive measures of RTIs can encourage them to follow these measures. The current study revealed that more than half of the studied subjects had negative attitude towards perceived benefits of the application of preventive measures for emerging RTIs (table V). This is in the line with the result of a study conducted by Tadesse et al.,.(2020) ${ }^{(48)}$, who found that more than half of their participants had low perceived benefits regarding the prevention of RTIs.

It was found in this study that more than two fifths of the studied employees agreed that following preventive measures can protect them from emerging RTIs. The results of Hassan N. et al., (2020) ${ }^{(38)}$, are nearly in the same line who revealed that the majority of participants (81.3\%) believe in effectiveness of precautions against COVID-19 to prevent spread of the disease.

It was reported that the most frequently reported method of protection against many various virus transmission is hand washing Souli and Dilucca, (2020) ${ }^{(29)}$. In this study, more than two fifths of the 
studied employees agreed that they think that using soap or alcohol reduces the infection of respiratory system (Table IV). This is nearly in the same line with the results of another study by Gudi et al., (2020) ${ }^{(30)}$, who revealed that the majority of the study participants believe that maintaining good personal hygiene, washing hands frequently using soap, avoiding handshaking behavior and avoiding placing fingers in eyes, nose and mouth would prevent the spread of the infection.

The results of this study revealed also that more than two fifths of the studied employees agreed that they will have no chance of getting infected with emerging RTIs when they get away from the crowd (Table IV). This could be attributed to the current huge propaganda by media and health organizations about the importance of social distance to prevent dissemination of COV-19 between populations. In the same line, Brian et al., (2020) ${ }^{(6)}$, indicated that the social distancing efforts implemented in Louisville, Kentucky, may be associated with a decrease in incidence of common respiratory viruses. As well, Wong et al., (2020) ${ }^{(28)}$, reported that the participants had positive attitudes regarding prevention of COVID-19 infection and often implemented recommended

disease-preventive measures, where $88.1 \%$ of them maintaining social distance.

More than one third of the studied employees in the current study agreed that taking the flu vaccine can reduce the risk of diseases of respiratory system (Table IV). This could be attributed to their correct knowledge about preventive measures of emerging respiratory tract infection. This is supported by Goni et al., (2019) ${ }^{(22)}$, who found that most of the participants agree that RTIs could be prevented by receiving vaccinations.

Perceived barriers are considered the main indicator for behavioral change. The perceived barriers are important and effective constructs of the health belief model because the individuals should take control over the barriers to behavior despite their inner desire to engage in preventive behavior. Excessive barriers can be obstacles and prevent the initiation of desired health behaviors.

In the current study, three fifths of the studied employees agreed that shame of wearing personal protective devices (PPD) is a reason for not to using it. And more than one fifth of them agreed that the difficulty of breathing when wearing mask prevents them from using it (Table 
IV).This is supported bySim et al., (2014) (24),

who stated that perceived barriers include experience or perception of personal discomfort and sense of embarrassment. Also, this result is nearly in the same line with Barakat and Kasemy, (2020) ${ }^{(45)}$, who mentioned that, their participants had less perceived barriers to preventive individual behaviors, such as hand washing, but environmental barriers such as shortage of masks, alcohol pads, and disinfectant agents strongly influenced the behaviors.

Cues to action are internal and external factors influencing individual's behavior toward health. In this study we assessed beliefs of the studied employees toward the motivators for the application of preventive measures for emerging RTIs. We found that more than one third of the studied employees reported that they had a previous attack of RTIs and they did not want to repeat the infection again. It was also found in this study that more than one quarter of the studied employees agreed that others' use of personal protective devices motivates them to imitate them (Table IV).

In addition, about one quarter of the studied employees agreed that cheap masks and disinfectants needed to fight the infection encourage them to use it. This may be attributed to the effect of socioeconomic status on the attitudes and beliefs of the people. Furthermore, it highlights the importance of the role of the government and health organizations to save the required protective needs used to prevent the infectious diseases especially in case of epidemics.

Self-efficacy is considered as level of a person's confidence in his or her ability to successfully perform desired behavior. This indicates that promoting healthy behavior needs empowering individual to follow healthy instructions. In this study we found that more than two fifths of the studied employees agreed that they can carry out the protective measures and wear the mask properly in the crowded areas, avoid coughing in the face of others and avoid direct contact with the patients with RTIs (Table IV).

On the other hand, the studied employees showed negative belief regarding their self efficacy to follow the preventive measures. This may be attributed to the lower economic status of the employees as the highest frequencies of them were clerical workers. This results is in agreement with the study of Guidry et al.,(2019) ${ }^{(49)}$, who reported that their subjects reflected a low level of expressed self-efficacy. In the 
same line, Barakat and Kasemy, (2020)

${ }^{(45)}$, reported that their participants ability

to follow preventive instructions and cues showed decreases in the scores over the three interview periods. In contrast to this result, Wong et al.,(2020) ${ }^{(28)}$, reported that more than $80 \%$ believed that they could protect themselves against the disease and that the pandemic would eventually be eradicated.

There is no doubt that the person's characteristics have a great effect on his beliefs. In the same context, the current study revealed that high significant positive correlations were found between the study employees' total beliefs score about emerging RTIs and their age, marital status and level of education and significant positive correlation with sex. On the other hand, Kandeel et al.,(2014) (50), demonstrated that results regarding beliefs and perceptions did not appear to differ between higher and lower educated groups or between genders. In the same context, Wong et al., (2020) ${ }^{(28)}$, reported that the participants expressed certain misconceptions regarding the prevention of COVID-19 infection. Participants, who were male, had a secondary school education or lower and who perceived a lower risk of being infected.
Finally, there was a significant positive correlation between the total knowledge score of the studied employees and their total beliefs' score regarding emerging RTIs based on HBM in this study. This means that the increase of the studied subjects' knowledge is strongly associated to their beliefs regarding emerging RTIs and its preventive measures. This result seems to be logical because if the awareness increased, the perceived susceptibility, severity, benefits, cues of actions, and self-efficacy to overcome the barriers to prevent diseases would also be increased. This result is in the same line of Elgzar et al.,(2020) ${ }^{(43)}$, who illustrated that there are positive, statistically significant correlations between participants' total HBM score and their total awareness score. This highlights the importance of improving the knowledge of employees at risk and all the population about emerging RTI and its preventive measures which in role will enhance their beliefs and affect their preventive behaviors.

\section{Conclusion:}

Generally, the studied subjects present a low level of knowledge and negative attitude towards emerging RTIs, the highest frequencies of the studied subjects gave incorrect answers related to causes, 
types and complications of emerging RTIs.

More than one third of them gave incorrect answers related to the method of protection against virus transmission. The most frequently reported source of knowledge about emerging respiratory infections was relative and friends or neighbors. Our findings revealed that studied employees show negative beliefs towards preventive measures for the emerging respiratory infection particularly regarding the barriers and cues of action related to use of preventive measures against the emerging respiratory infections. However, Shame of wearing personal protective devices (PPD) was the most perceived barrier for following preventive measures followed by the high price of disinfectants. While, the majority of the studied employee disagreed that they feel physical and psychological comfort when they do not suffer from respiratory diseases. Significant correlations were observed between the studied subjects' age, marital status, level of education and the total level of beliefs and their level of knowledge.

\section{Recommendations:}

Based on the results of the current study it was recommended that:

- An extensive educational health campaign should be provided to the public to create awareness and gain positive attitude and beliefs regarding the emerging RTIs and its prevention.

- The gap recognized in this study can serve as baseline data to design effective interventions to evaluate the prevention strategies for prevention of emerging RTIs among the public.

- Further assessment of factors influencing public beliefs and compliance with preventive measures of emerging RTIs is recommended.

\section{References:}

1. Hui DS, Azhar EI, Kim YJ, Memish ZA, Oh MD, Zumla A. Middle East respiratory syndrome coronavirus: Risk factors and determinants of primary, household, and nosocomial transmission. Lancet Infect. Dis. 2018; 18(1): 217- 227.

2. Centers for Disease Control and Prevention. Middle East Respiratory Syndrome(MERS). (2015); Retrieved from:http://www.cdc.gov/coronavirus/ mers /index.html

3. Ciotti M, Maurici M, Santoro V, Coppola L, Sarmati L, De Carolis G, et al. Viruses of respiratory tract: An observational retrospective study on 
hospitalized patients in Rome, Italy. Microorganisms. 2020; 8(4):1-13.

4. European Respiratory Society. The Global Impact of Respiratory DiseaseSecond Edition, Forum of International Respiratory Societies. 2017.Available:https://www.mendeley .com/catalogue/a00d4a7d-3178-3622a202-bc855b01f6b0/

5. Seto W H, Conly J M, Pessoa-Silva C L, Malik M, Eremin S. Infection prevention and control measures for acute respiratory infections in healthcare settings: An update. EMHJ - Eastern Mediterranean Health Journal. 2013. Available from: (European Respiratory Society, 2017) https://apps.who.int/iris/handle/10665 /118445

6. Bohn B. The incidence of common respiratory viruses during the COVID19 Pandemic: Results from the Louisville COVID-19 Epidemiology Study. J. Respir. Infect. 2020; 4(1):812.

7. Al-Romaihi H E, Smatti M K, Ganesan N, Nadeem S, Farag E, Coyle PV, et al. Epidemiology of respiratory infections among adults in Qatar (2012-2017). PLoS ONE. 2019; 14: e0218097.
8. Cilloniz C, Martin-Loeches I, GarciaVidal C, San Jose A, Torres A. Microbial etiology of pneumonia: Epidemiology, diagnosis and resistance patterns. Int. J. Mol. Sci. 2016; 17: piiE2120. Available from: http//:www.mdpi.com/1422$0067 / 17 / 12 / 2120$

9. Rowlinson E, Dueger E, Mansour A. Incidence and etiology of hospitalized acute respiratory infections in the Egyptian Delta. Influenza Other Respir. Viruses. 2017;11(1):23-32.

10. Elhakim M, Kandil K, Abd Elaziz M, Anwar A. Epidemiology of Severe Acute Respiratory Infection (SARI) cases at a sentinel site in Egypt, 201315. Journal of Public Health (Oxford, England). 2020; 4 2(3):525-533.

11. Park S, Park Y, Song Y, How S, Jung K. Emerging respiratory infections threatening public health in the AsiaPacific region: A position paper of the Asian Pacific Society of Respirology. Respirology. 2019; 24: 590-597.

12. Allegranzi B, Memish ZA, Donaldson L, Pittet D. World Health Organization Global Patient Safety Challenge Task Force on Religious and Cultural Aspects of Hand Hygiene; World Alliance for Patient Safety. Religion and culture: Potential undercurrents 
influencing hand hygiene promotion in health care. Am J. Infect Control. $2016 ; 37: 28-34$.

13. WHO. Emergencies preparedness, response. Middle East respiratory syndrome coronavirus (MERS-CoV) Oman. [Accessed 26 Nov 2017.] Available from:

URL: http://www.who.int/csr/don/ $10-$ november-2017-mers-oman/en/

14. Beran D, Zar J, Perrin C, Menezes M, Burney P. Forum of International Respiratory Societies working group. Burden of asthma and chronic obstructive pulmonary disease and access to essential medicines in lowincome and middle-income countries. Lancet Respir. Med. 2015; 3: 159170. Available from: http://www.thelancet.com/journals/lan res/article/PIIS2213-2600(15)000041/abstract

15. Noé A, Ribeiro R M, Anselmo R, Maixenchs M, Sitole L, Munguambe $\mathrm{K}$, et al. Knowledge, attitudes and practices regarding tuberculosis care among health workers in Southern Mozambique. BMC Pulm. Med. 2017; 17: 2 .

16. Abd Wahab F, Abdullah S, Abdullah J M, Jaafar H, Noor S M, Mohammad $\mathrm{W}$, et al. Updates on knowledge, attitude and preventive practices on tuberculosis among healthcare workers. Malays. J. Med Sci. MJMS 2016; 23: 25. [PubMed]

17. Elbialy A A, El-Shafie I, Ebrahim H, Khaton S. Effect of preventive program about reproductive tract infections on knowledge, beliefs and practices among rural women based on Health Belief Model. International Journal of Novel Research in Healthcare and Nursing. 2019; 6(1): 748-764.

18. Chu D K, Akl E A, Duda S, Solo K, Yaacoub S, Schünemann, et al. Physical distancing, face masks and eye protection to prevent person-toperson transmission of SARS-CoV-2 and COVID-19: A systematic review and meta-analysis. Lancet. S0140673620311429. 2020; 6(20): 31142-9. Available from: https://doi.org/10.1016/S0140-6736

19. Adema IW, Kamau E, Uchi Nyiro J, Otieno GP, Lewa C, Munywoki PK. Surveillance of respiratory viruses among children attending a primary school in rural coastal Kenya. Wellcome Open Res. 2020; 5(1):63.

20. Stone PW, Hasan S, Quiros D, Larson EL. Effect of guideline implementation on costs of hand 
hygiene. Nurs. Econ. 2017; 25(5):27984.

21. Ghanbari M K, Farazi AA, Shamsi M, Khorsandi M, Esharti B. Measurement of the Health Belief Model (HBM) in nurses hand hygiene among the hospitals. World Appl. Sci. J. 2014; 31(5):811-8.

22. Goni MD, Hasan H, Naing NN, WanArfah N, Deris ZZ, Arifin WN, et al. Assessment of knowledge, attitude and practice towards prevention of respiratory tract infections among hajj and umrah pilgrims from Malaysia in 2018. Int. J. Environ Res. Public Health. 2019;16(22):1-11.

23. Alsulaiman S, and Rentner $\mathrm{T}$. The Health Belief Model and Preventive Measures: A Study of the Ministry of Health Campaign on Coronavirus in Saudi Arabia. Journal of International Crisis and Risk Communication Research. 2018; 1(1), 27-56. doi: 10.30658/jicrcr.1.1.3.

24. Sim S W, Moey K S, Tan N C. The use of facemasks to prevent respiratory infection: A literature review in the context of the Health Belief Model. Singapore Medical Journal. 2014; 55(3):160-167. doi: 10.11622/smedj.2014037.
25. Al-Ansary L, Bawazeer GA, Beller EM, Clark J, Conly JM, Del Mar C, et al. Physical interventions to interrupt or reduce the spread of respiratory viruses. Part 2: Hand hygiene and other hygiene measures: Systematic review and meta-analysis. Bol Med Hosp Infant Mex. 2020;77(3):142-5.

26. International Labour Organization. In the face of a pandemic: Ensuring Safety and Health at Work [Internet]. 2020. 50 Available from: https://www.ilo.org/wcmsp5/groups/p ublic/---ed_protect/---protrav/--safework/documents/publication/wcm s_742463.pdf\%0Ahttps://www.dgs.pt/ saude-ocupacional/documentos-so/oitcampanha-sst-2020-pdf.aspx

27. Ogolodom MP, Mbaba AN, Alazigha N, Erondu OF, Egbe NO, Golden I , Ugwuanyi DC, Achi GI and Eke CM. Knowledge, attitudes and fears of health care workers towards the Corona Virus Disease. iMedPub Journals. 2020; 1-10. doi: 10.36648/1791-809X.S1.002.

28. Wong C L, Chen J, Chow KM, Law BMH, Chan DNS, So WK, et al. Knowledge, attitudes and practices towards COVID-19 amongst ethnic minorities in Hong Kong. International Journal of Environmental Research 
and Public Health. 2020; 17(21): 1-13. doi: 10.3390/ijerph17217878.

29. Souli D, Dilucca M. Knowledge, attitude and practice of secondary school students toward COVID-19 epidemic in Italy: A cross selectional study. 2020; 1-11. doi:

$10.1101 / 2020.05 .08 .084236$. It is made available under a CC-BY-NCND 4.0 International license.

30. Gudi SK, Undela K, Venkataraman R, Mateti UV, Chhabra M, Nyamagoud $\mathrm{S}$, et al. Knowledge and Beliefs towards Universal Safety Precautions to flatten the curve during Novel Coronavirus Disease (nCOVID-19) Pandemic among general Public in India: Explorations from a National Perspective. 2020; preprint doi: https://doi.org/10.1101/2020.03.31.20 047126 It is made available under a CC-BY 4.0 International license .

31. Joshi K P, Madhura L, Jamadar D. Knowledge and awareness among nursing students regarding the COVID-19: A cross sectional study. International Journal Of Community Medicine And Public Health. 2020; 7(7): 2518. doi: 10.18203/23946040.ijcmph20202536.

32. Modi PD, Kumar P, Solanki R, Modi J, Chandramani S, Gill N. Hand
Hygiene Practices Among Indian Medical Undergraduates: A Questionnaire-Based Survey. Cureus. 2017; 9(7):PP:1-16. doi: 10.7759/cureus. 1463.

33. Rahman A. and Sathi N J. Knowledge, attitude, and preventive practices toward COVID-19 among Bangladeshi internet users. Electronic Journal of General Medicine. 2020; 17(5). doi: 10.29333/ejgm/8223.

34. Diaz-Quijano FA, Martínez-Vega RA, Rodriguez-Morales AJ, Rojas-Calero RA, Luna-González ML, DíazQuijano RG. Association between the level of education and knowledge, attitudes and practices regarding dengue in the Caribbean region of Colombia. BMC Public Health. 2018;18(1):1-10.

35. Ogolodom MP, Mbaba AN, Alazigha N, Erondu OF, Egbe NO,Golden I, et al. Knowledge, attitudes and fears of health care workers towards the Corona Virus Disease. Health Sci. J. 2020; Sp. Iss 1: 002:1-10. doi: 10.36648/1791-809X.S1.002.

36. Nour MO, Babilghith AO, Natto HA, Al-Amin FO A S. Knowledge, attitude and practices of healthcare providers towards MERS-CoV infection at Makkah hospitals, KSA. International 
Research Journal of Medicine and

Medical Sciences. 2015; 3(4): 103-

112. Available from:

https://www.researchgate.net/publicati on/309011322.

37. Dwivedi Y K., Rana NP, Tajvidi M, Lal B, Sahu GP and Gupta A, . Exploring the Role of Social Media in e-Government, 2017; 97-106. doi: $10.1145 / 3047273.3047374$.

38. Hassan NM, El-feky AA. Risk perceptions, attitude and preventive practices of Egyptians towards COVID-19. 2020. Available from: https://www.researchsquare.com/articl e/rs-89882/v1

39. Zhong B L, Luo W, Li HM, Zhang QQ, Liu XG, Li WT, et al. Knowledge, attitudes, and practices towards COVID-19 among chinese residents during the rapid rise period of the COVID-19 outbreak: A quick online cross-sectional survey. International Journal of Biological Sciences. 2020; 16(10):1745-1752.

40. Kale M S, Federman AD, Krauskopf K, Wolf M, O’Conor R, Martynenko $\mathrm{M}$, et al. The association of health literacy with illness and medication beliefs among patients with chronic obstructive pulmonary disease. PLoS
ONE, 2015; 10(4): 1-10. doi:

10.1371/journal.pone.0123937.

41. Abdelhafiz A S, Alorabi M. Social Stigma: The Hidden Threat of COVID-19. Frontiers in Public Health. 2020; 8(8): 2-5. doi:

10.3389/fpubh.2020.00429.

42. Spencer J, Shutt D, Moser S, Clegg H, Wearing $\mathrm{H}$, Mukundan $\mathrm{H}$, et al. Epidemiological parameter review and comparative dynamics of influenza, respiratory syncytial virus, rhinovirus, human coronavirus, and adenovirus. 2020;

doi:

10.1101/2020.02.04.20020404.

43. Elgzar WT, Al-Qahtani AM, Elfeki NK, Ibrahim HA. Covid-19 outbreak: Effect of an educational intervention based on health belief model on nursing students' awareness and health beliefs at Najran university, kingdom of Saudi Arabia. African Journal of Reproductive Health. 2020; 24(2 Special Edition COVID-19), 78-86. doi: 10.29063/ajrh2020/v24i2s.12.

44. Brug J, Aro A R, Richardus J H. Risk perceptions and behaviour: Towards pandemic control of emerging infectious diseases: Iional research on risk perception in the control of emerging infectious diseases. International Journal of Behavioral 
Medicine. 2009; 16(1): 3-6. doi: 10.1007/s12529-008-9000-x.

45. Barakat A M, Kasemy Z A. Preventive health behaviours during coronavirus disease 2019 pandemic based on health belief model among Egyptians. Middle East Current Psychiatry. 2020; 27(1). doi: 10.1186/s43045-02000051-y.

46. Ahmad A, Khan MU, Jamshed SQ, Kumar BD, Kumar GS, Reddy PG and Ajmera S. Are healthcare workers ready for ebola? An assessment of their knowledge and attitude in a referral hospital in south india. Journal of Infection in Developing Countries. 2016;10(7):747-.doi:.3855/jidc.7578.

47. Zegarra-Valdivi J, Chino Vilca B N, Ames-Guerrero R J. Knowledge, perception and attitudes in Regard to COVID-19 Pandemic in Peruvian Population. 2020; doi: 10.31234/osf.io/kr9ya.

48. Tadesse T, Alemu T, Amogne G, Endazenaw G, Mamo E. Predictors of coronavirus disease 2019 (Covid-19) prevention practices using health belief model among employees in Addis Ababa, Ethiopia. Infection and Drug Resistance. 2020; 13(1):375161. doi: 10.2147/IDR.S275933.

49. Guidry J, Carlyle KE, LaRose JG, Perrin P, Messner M, Ryan M. Using the health belief model to analyze instagram posts about Zika for public health communications. Emerging Infectious Diseases. 2019; 25(1): 179180. doi: 10.3201/eid2501.180824.

50. Kandeel A, El-Shoubary W, Hicks LA, Abdel Fattah M, Dooling K, Lohiniva AL et al. Patient attitudes and beliefs and provider practices regarding antibiotic use for acute respiratory tract infections in minya, Egypt. Antibiotics. 2014; 3(4): 632644. doi: 10.3390/antibiotics3040632. 